\title{
Different sources of sulfur in diets of adult cats on the urinary parameters and acid-base balance
}

\section{Dóris Pereira Halfen ${ }^{1}$ Alexandre de Mello Kessler ${ }^{2}$ Luciano Trevizan $^{2}$ Juliana Toloi Jeremias ${ }^{3}$ Thiago Henrique Annibale Vendramini ${ }^{4}$ João Paulo Fernandes Santos ${ }^{4}$ Patricia Massae Oba ${ }^{4}$ Fabio Alves Teixeira ${ }^{1}$ Marcio Antonio Brunetto ${ }^{4 *}$ - Aulus Cavalieri Carciofi ${ }^{3}$}

${ }^{1}$ Departamento de Clínica Veterinária, Universidade de São Paulo (USP), São Paulo, SP, Brasil.

${ }^{2}$ Departamento de Zootecnia, Universidade Federal do Rio Grande do Sul (UFRGS), Porto Alegre, RS, Brasil.

${ }^{3}$ Departamento de Clínica e Cirurgia Veterinária, Universidade Estadual Paulista (UNESP), Jaboticabal, SP, Brasil.

${ }^{4}$ Departamento de Nutrição e Produção Animal, Universidade de São Paulo (USP), Av. Prof. Dr. Orlando Marques de Paiva, 87, Cidade

Universitária, 05508-270, São Paulo, SP, Brasil. E-mail: mabrunetto@usp.br. *Corresponding author.

ABSTRACT: Urolithiasis is a common disorder in the veterinary clinic and is considered as one of the most frequently cause of morbidity. This disorder is closely associated with urinary $\mathrm{pH}$ and nutrition plays a key role in the control of this disease, because through dietary manipulation it is possible to modify the urinary $\mathrm{pH}$. Sulfur is considered macroelement with a strong influence on the acid-base status and may be crucial to control urinary $\mathrm{pH}$ in cats. The purpose of this study was to evaluate the effects of addition of different sources of sulfur (S) in the diet of cats on the urinary parameters and acid-base balance. Forty-two healthy adult cats were divided into 3 groups, and each group of 14 cats received 7 diets in a complete randomized block design. Calcium sulfate (CaSO , DL-methionine (DLM) and methionine hydroxy analog (MHA) were added to a control diet in two levels $(1.28 \mathrm{~g} \mathrm{~S} / \mathrm{kg}$ and $2.56 \mathrm{~g} \mathrm{~S} / \mathrm{kg})$ to formulate 6 other experimental diets. The acid-base balance was evaluated by hemogasometry in samples of venous blood. The DLM at the highest level and MHA differed of the control diet in relation to urinary $\mathrm{pH}(\mathrm{P}<0.05)$. Calcium sulfate; although, not differentiated from the control diet, has been shown to alter urinary $\mathrm{pH}$ despite its zero electrolyte balance. Apparently, the alkalizing effect of calcium was not sufficient to avoid sulfate acidification of the urine. Treatments showed no alteration of the acid-base balance of the animals and no affect the consumption of the diets.

Key words: calcium sulfate, felines, methionine, methionine hydroxy analogue, urolithiasis.

Efeitos da adição de diferentes fontes de enxofre na dieta de gatos adultos em parâmetros urinários e equilíbrio ácido-básico

RESUMO: A urolitíase é uma desordem comum na clínica veterinária, considerada como uma das maiores causas de morbidade. Esta desordem está intimamente associada ao pH urinário sendo que a nutrição desempenha papel fundamental no controle dessa doença, pois através da manipulação dietética é possível modificar o pH urinário. O enxofre é considerado um macroelemento com forte influência no equilíbrio ácido-básico e pode ser crucial para controlar o pH urinário em gatos. O objetivo deste estudo foi avaliar os efeitos da adição de diferentes fontes de enxofre (S) na dieta de gatos nos parâmetros urinários e no equilíbrio ácido-básico destes animais. 42 gatos adultos saudáveis foram divididos em 3 grupos e cada grupo de 14 gatos recebeu 7 dietas em um delineamento de blocos ao acaso. O sulfato de cálcio $\left(\mathrm{CaSO}_{4}\right.$, a DL-metionina (DLM) e a metionina hidróxi-análoga (MHA) foram adicionados a uma dieta controle em dois níveis (1,28g $\mathrm{S} / \mathrm{kg}$ e 2,56g S/kg) para formular outras 6 dietas experimentais. O equilibrio ácido-básico foi avaliado por hemogasometria em amostras de sangue venoso. O DLM no teor mais alto e MHA diferiram da dieta controle em relação ao pH urinário $(P<0,05)$. O sulfato de cálcio, embora não tenha diferido da dieta controle, demonstrou alterar o pH urinário apesar do seu equilibrio eletrolítico nulo. Aparentemente, o efeito alcalinizante do cálcio não foi suficiente para anular a acidificação da urina pelo sulfato. Os tratamentos não apresentaram alteração do equilibrio ácido-básico dos animais e não afetaram o consumo das dietas experimentais.

Palavras-chave: felinos, metionina, metionina hidróxi-análoga, sulfato de cálcio, urolitíase

\section{INTRODUCTION}

The macroelement composition of diets has a strong influence on the acid-base status and urinary pH of animals (KIENZLE et al., 1991; ALLEN \& KRUGER, 2000; WAGNER et al., 2006).
Treatment for urolithiasis in dogs and cats has been advent of new studies in the past century and as uroliths management is evolving, nutrition remains a subject of much clinical interest and debate in the management of these animals (LULICH et al., 2016) since the urine $\mathrm{pH}$ has strong influence on 
certain types of urolith formation (BARTGES \& CALLENS, 2015; BARTGES, 2016).

Struvite uroliths are associated with alkaline $\mathrm{pH}$ (close to or greater than 7.0) (LANGSTON et al., 2008). Reduction of urinary $\mathrm{pH}$ has been shown to be effective in decreasing the incidence of formation of these crystals (MARKWELL et al., 1998), and supplements are recommended to maintain urine at a $\mathrm{pH}$ between 6.2 and 6.4 for the prevention of these uroliths and between $\mathrm{pH} 5.9$ and 6.1 for dissolution (ALLEN \& KRUGER, 2000).

Addition of sulfur to cat diets may occur through sulfur-containing amino acids, like methionine, cysteine and taurine, and the supplementation of some microelements such as iron and copper sulfates. The DL-methionine (DLM) can be used to correct the dietary amino acid balance and also as a urinary acidifier (FUNABA et al., 2000). Methionine hydroxy analog (MHA) has been recently introduced into the formulation of diets for farm animals in order to replace DLM. No studies with cats were reported with this molecule. Theoretically, it would have higher acidifying capacity compared to methionine. Due to the lack of nitrogen, MHA receives a nitrogen atom in the liver and transforms it into L-methionine, a process that could reduce the urinary excretion of nitrogen (ammonia), thus lowering the urine buffering capacity (MARTÍNVENEGAS et al., 2006). In other species, as in pigs, the $\mathrm{pH}$ of the urine could be acidified by the inclusion of calcium sulfate (CaSO4) in different doses, being a higher dose responsible for greater acidification (CANH et al. 1998).

During food formulation, several approaches and ingredients can be used to balance macroelements in order to achieve a properly balanced diet. However, nutritionists need to have adequate information about the buffering potential of each mineral source to make the correct decision during food formulation. Therefore, the present study evaluated the effects of the addition of three sulfur sources [calcium sulfate (CaSO4), DLM and MHA] in the diet on different urinary parameters and acidbase equilibrium of adult cats.

\section{MATERIALS AND METHODS}

\section{Animals and experimental design}

The experiment was conducted at the Laboratory for Research on Nutrition and Nutritional Diseases of Dogs and Cats - Universidade Estadual Paulista, Jaboticabal, Brazil. All experimental procedures were approved by the Animal Ethics and Welfare Commission of FCAV/UNESP, protocol number $017648 / 11$. Cats belonged to the same laboratory colony. Cats' health was assessed prior to the beginning of the survey by clinical and hematologic examination, as well as by urine analysis.

Forty-two healthy, adult, mixed-breed cats aged $4 \pm 1.3$ years and $4.1 \pm 0.84 \mathrm{~kg}$ of body weight and seven experimental dry diets for cats were used. The experiment was conducted with 3 groups and each group of 14 cats received 7 diets in a randomized complete block design ( 2 cats/diet in each group), resulting in 6 cats/diet. Each block had a duration of 13 days with an interval of 2 days. Three sulfur sources, calcium sulfate, DLM, and MHA were added at two levels, 1.28 and $2.56 \mathrm{~g} \mathrm{~S} /$ $\mathrm{kg}$ of diet, into a basal extruded dry cat food with base excess (BE) around $100 \mathrm{mEq} / \mathrm{kg}$, previously ground in a cutting mill equipped with a $1 \mathrm{~mm}$ screen. In the control diet, no sulfur sources were added. After mixing all the ingredients, diets were pelleted. Pelletization is a low shear and temperature processing, so changes on added ingredients is not expected. Nutritional level was similar in all diets (Table 1) and all were within recommendations for adult cat maintenance (AAFCO, 2008).

The base excess $(\mathrm{mEq} / \mathrm{kg})$ was calculated by the formula: $\mathrm{EB}=(49.9 \times \mathrm{Ca})+(82.3 \times \mathrm{Mg})+$ $(43.5 \times \mathrm{Na})+(25.6 \times \mathrm{K})-(64.6 \times \mathrm{P})-(62.4 \times \mathrm{S})-$ $(28.2 \times \mathrm{Cl})$, the concentration of the elements being in $\mathrm{g} / \mathrm{kg} \mathrm{DM}$.

Cats were kept in individual stainless steel metabolic cages $(90 \times 80$ x $90 \mathrm{~cm})$ equipped with a system to separate feces and urine. Cats were fed once daily (08:00h) and the metabolizable energy of diets was calculated from their chemical composition, through the equation estimation methodology described by the Nutrition Requirements of Dogs and Cats (NRC, 2006). The amount of food supplied was calculated as $130 \mathrm{kcal}$ ME per $\mathrm{kg}^{0.4}$ (NRC, 2006). Food was offered placed ad libitum until the next meal. Food intake was daily measured by weighting offered food and refusals. Water was provided ad libitum.

\section{Urine analysis}

The first 7 days were used for diet adaptation and the last 6 days for total urine collection, in two periods. In the first period (days 8-10), urine was collected twice daily in plastic containers with $0.1 \mathrm{~g}$ of thymol $(0.1 \mathrm{~g}$ per $100 \mathrm{~mL}$ of urine) and kept refrigerated $\left(4^{\circ} \mathrm{C}\right)$. Immediately after collection, urine volume was measured, as well as urine density with a refractometer (ATAGO CO., LTD; model 
Table 1 - Ingredient and chemical composition of the experimental diets.

\begin{tabular}{|c|c|c|c|c|c|c|c|}
\hline \multirow{2}{*}{ Item } & \multirow[b]{2}{*}{ Control } & \multicolumn{2}{|c|}{$\mathrm{CaSO}_{4}$} & \multicolumn{2}{|c|}{ DL-Methionine } & \multicolumn{2}{|c|}{ Methionine hydroxyl-analogue } \\
\hline & & $(1.28 \mathrm{~S})$ & $(2.56 \mathrm{~S})$ & $(1.28 \mathrm{~S})$ & $(2.56 \mathrm{~S})$ & $(1.28 \mathrm{~S})$ & $(2.56 \mathrm{~S})$ \\
\hline \multicolumn{8}{|c|}{ - } \\
\hline Commercial diet for cats ${ }^{1}$ & 98.63 & 98.63 & 98.63 & 98.63 & 98.63 & 98.63 & 98.63 \\
\hline Corn starch & 1.36 & 0.80 & 0.25 & 0.76 & 0.16 & 0.68 & 0 \\
\hline $\mathrm{CaSO}_{4}{ }^{2}$ & 0 & 0.55 & 1.11 & 0 & 0 & 0 & 0 \\
\hline DL-methionine ${ }^{3}$ & 0 & 0 & 0 & 0.60 & 1.20 & 0 & 0 \\
\hline Methionine analogue ${ }^{4}$ & 0 & 0 & 0 & 0 & 0 & 0.68 & 1.36 \\
\hline \multicolumn{8}{|c|}{ - } \\
\hline Dry matter & 93.7 & 93.1 & 92.7 & 92.1 & 92.9 & 92.7 & 92.2 \\
\hline Crude Protein & 30.8 & 30.4 & 30.4 & 30.5 & 30.7 & 30.4 & 30.9 \\
\hline Fat & 13.7 & 13.8 & 13.6 & 14.3 & 14.2 & 13.8 & 13.3 \\
\hline Crude Fibre & 2.8 & 2.6 & 2.5 & 2.5 & 2.5 & 2.5 & 2.3 \\
\hline Ash & 8.1 & 8.3 & 8.8 & 7.9 & 8.3 & 8.1 & 8.1 \\
\hline Calcium & 1.57 & 1.66 & 1.83 & 1.51 & 1.50 & 1.53 & 1.54 \\
\hline Phosphorus & 1.22 & 1.25 & 1.26 & 1.28 & 1.24 & 1.25 & 1.27 \\
\hline Magnesium & 0.15 & 0.15 & 0.14 & 0.14 & 0.16 & 0.15 & 0.15 \\
\hline Sodium & 0.51 & 0.54 & 0.53 & 0.54 & 0.50 & 0.53 & 0.53 \\
\hline Potassium & 0.79 & 0.70 & 0.77 & 0.76 & 0.71 & 0.72 & 0.74 \\
\hline Chlorine & 0.66 & 0.67 & 0.65 & 0.67 & 0.67 & 0.66 & 0.65 \\
\hline Sulfur & 00.42 & 0.53 & 0.68 & 0.53 & 0.70 & 0.59 & 0.66 \\
\hline Food base excess ${ }^{5}, \mathrm{mEq} / \mathrm{kg}$ of dry matter & 99.93 & 44.67 & 40.56 & -46.21 & -122.04 & -49.64 & -95.93 \\
\hline
\end{tabular}

${ }^{1}$ Ingredient composition: maize, maize gluten meal, meat meal, wheat bran, soybean meal, fish meal, poultry by-products meal, poultry fat, beet pulp, sodium chloride, flavour, calcium propionate, potassium sorbate, potassium chloride, vitamin and mineral premix. ${ }^{2}$ Labsynth produtos para laboratório Ltda, Diadema, Brazil, 98\% purity. ${ }^{3}$ Evonik Degussa Corporation, Guarulhos, Brazil, $99 \%$ purity. ${ }^{4}$ Alimet, Novus International Inc., Indaiatuba, Brazil, $88 \%$ purity. ${ }^{5}$ Food base excess $(\mathrm{mEq} / \mathrm{kg})=49.9^{*} \mathrm{Ca}+82.3^{*} \mathrm{Mg}+43.5^{*} \mathrm{Na}+25.6^{*} \mathrm{~K}-64.6^{*} \mathrm{P}-62,4^{*} \mathrm{~S}-$ $28.2^{*} \mathrm{Cl}$, macroelements amounts in $\mathrm{g} / \mathrm{kg}$ of dry matter.

T2-N3), and $\mathrm{pH}$ with a $\mathrm{pH}$ meter (model DM20, DIGIMED São Paulo, Brazil). The urine collected in $24 \mathrm{~h}$ was maintained frozen. The urine produced in $72 \mathrm{~h}$ was mixed and evaluated for sodium $(\mathrm{mmol} / \mathrm{L})$ and potassium $(\mathrm{mmol} / \mathrm{L})$ using an ion-selective method (AVL unit - OMNI4 - Roche, Brandford, USA), and chloride (mmol/L) was determined by the Labtest - mercuric thiocyanate methodology (Ref. 49 Chlorides - Labtest) followed by spectrophotometry. In the second period (days 11-13), urine was collected twice a day in plastic containers with $\mathrm{HCl} 6 \mathrm{~N}(2 \mathrm{~mL}$ per $100 \mathrm{~mL}$ of urine) and kept refrigerated $\left(4^{\circ} \mathrm{C}\right)$. This measure has been reported as sufficient to reduce the urinary $\mathrm{pH}$ to about $1-2$, preventing the formation of crystals (GRIYTH \& DUNN, 1978). The urine collected in $24 \mathrm{~h}$ was frozen. Calcium $(\mathrm{mg} / \mathrm{dL})$, phosphorus $(\mathrm{mg} / \mathrm{dL})$, magnesium $(\mathrm{mg} / \mathrm{dL})$ and sulfur $(\mathrm{g} / \mathrm{L})$ were measured in urine produced in $72 \mathrm{~h}$. Calcium quantification was analyzed using colorimetric method (CPC - cresolphthalein, calcium Liquiform Ref 90, Labtest, Minas Gerais, Brazil). Quantitative analysis of urinary phosphorus was made by a modified endpoint reaction UV method of Daly and Ertingshausen (Ref. 42 Liquiform UV Phosphorus, Labtest, Minas Gerais, Brazil), and magnesium by the colorimetric method (Magon sulfonate, magnesium Ref. 90, Labtest, Minas Gerais, Brazil). Sulfur was measure using the turbidimetric method as described by AOAC (2006).

\section{Blood gas analysis}

Blood gas analysis of venous blood was evaluated after $13 \mathrm{~d}$ of diet consumption. At 08:00am (before feeding) and 02:00pm (six 
hours after feeding), $0.5 \mathrm{~mL}$ of venous blood was collected from the medial saphenous vein without compression. Before blood was collected, the syringe was washed out with a heparin solution, leaving the dead-space filled. Blood was immediately analyzed for $\mathrm{pH}$, sodium $(\mathrm{Na})$, potassium (K), ionized calcium (Cai), the partial pressure of carbon dioxide $\left(\mathrm{PCO}_{2}\right)$, bicarbonate $\left(\mathrm{HCO}_{3}\right)$, base excess (BE) and osmolality (Osm) using Omini C Blood Gas Analyzer (Roche Diagnostics, Indianapolis, USA).

\section{Chemical analysis}

Food samples were ground in a cutting mill equipped with $1 \mathrm{~mm}$ screen and analyzed for dry matter (DM) by submitting samples to oven drying; ash by muffle furnace incineration; and crude protein (CP) using the Kjeldahl method (AOAC, 2006). Samples were also analyzed for acid-hydrolyzed fat (AHF) using Soxhlet apparatus, and crude fiber (CF) using the Weende method (AOAC, 2006). Nitrogenfree extract (NFE) was calculated by subtracting ash, $\mathrm{AHF}, \mathrm{CP}$ and $\mathrm{CF}$ components from DM (NFE = DM-ash-AHF-CP-CF). Minerals were analyzed after nitric-perchloric digestion. Phosphorus was measured with the spectrophotometer using the vanadatemolybdate method. Calcium, potassium, magnesium, chloride, and sodium were measured by flame atomic absorption spectrophotometry.

\section{Statistical analysis}

Data were analyzed using the statistical software SAS (version 9.2, SAS Institute Inc., Cary, USA); analyzed in a randomised block design by ANOVA, seven treatments composed of diets in three blocks, and the averages of treatments were compared by the SNK test. The blocking factor was time, design adopted as the laboratory cannot evaluate 42 cats simultaneously. For the urinary $\mathrm{pH}$ response, multiple regression analysis of the $\mathrm{S}$ levels was performed, comparing the different sources using the "Comparison of Regression Lines" module of Statgraphics plus 4.1. Values of $\mathrm{P}<0.05$ were considered significant.

\section{RESULTS}

Cats showed no clinical changes throughout the experiment. The average daily food intake was $12.3 \pm 3.6 \mathrm{~g} / \mathrm{kg}$ of $\mathrm{DM} \mathrm{BW} / \mathrm{d}(46.9 \pm 13.7 \mathrm{kcal} / \mathrm{kg}$ of BW/d). Only the ionic calcium (Cai) was below normal hemogasometric parameters for adult cats in all experimental diets, before and after the food supply. Food consumption and blood gas values did not differ between groups (Table 2). The daily urine volume and

Table 2 - Dry matter intake and ion and gas analysis of venous blood of cats.

\begin{tabular}{|c|c|c|c|c|c|c|c|c|c|c|c|}
\hline & & & \multicolumn{2}{|c|}{$\mathrm{CaSO} 4$} & \multicolumn{2}{|c|}{ DL-Methionine } & \multicolumn{5}{|c|}{-----------Methionine hydroxyl-analogue----------- } \\
\hline \multicolumn{2}{|l|}{ Item } & Control & $(1.28 \mathrm{~S})$ & $(2.56 \mathrm{~S})$ & $(1.28 \mathrm{~S})$ & $(2.56 \mathrm{~S})$ & $(1.28 \mathrm{~S})$ & $(2.56 \mathrm{~S})$ & $\mathrm{CV}(\%)^{1}$ & SEM $^{2}$ & $\mathrm{p}$-Value \\
\hline \multicolumn{2}{|c|}{ Dry matter intake (g/kg BW/d) } & 10.3 & 12.7 & 11.1 & 12.1 & 13.7 & 13.4 & 12.9 & 25.31 & 3.32 & 0.450 \\
\hline \multicolumn{12}{|c|}{ 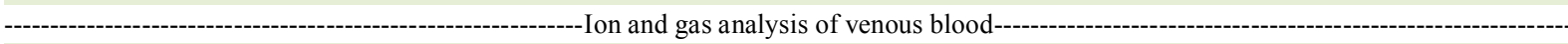 } \\
\hline \multirow{2}{*}{$\mathrm{pH}$ (venous) } & $8 \mathrm{~h}^{3}$ & 7.31 & 7.29 & 7.30 & 7.29 & 7.28 & 7.31 & 7.30 & 0.40 & 0.04 & 0.848 \\
\hline & $14 \mathrm{~h}^{4}$ & 7.30 & 7.29 & 7.29 & 7.29 & 7.30 & 7.32 & 7.29 & 7.29 & 0.33 & 0.504 \\
\hline \multirow{2}{*}{$\mathrm{PCO}_{2}(\mathrm{mmHg})$} & $8 \mathrm{~h}$ & 41.8 & 43.4 & 41.8 & 42.5 & 41.6 & 41.3 & 41.3 & 9.88 & 5.90 & 0.995 \\
\hline & $14 \mathrm{~h}$ & 44.1 & 43.2 & 44.8 & 44.1 & 43.2 & 41.8 & 43.2 & 5.63 & 3.38 & 0.749 \\
\hline \multirow[t]{2}{*}{$\mathrm{Na}(\mathrm{mmol} / \mathrm{L})$} & $8 \mathrm{~h}$ & 154 & 155 & 154 & 153 & 155 & 154 & 153 & 1.05 & 2.19 & 0.581 \\
\hline & $14 \mathrm{~h}$ & 154 & 157 & 154 & 153 & 154 & 154 & 153 & 1.06 & 2.93 & 0.449 \\
\hline \multirow[t]{2}{*}{$\mathrm{K}(\mathrm{mmol} / \mathrm{L})$} & $8 \mathrm{~h}$ & 3.74 & 3.94 & 3.89 & 3.67 & 3.80 & 4.15 & 3.72 & 10.86 & 0.60 & 0.779 \\
\hline & $14 \mathrm{~h}$ & 3.74 & 3.94 & 3.58 & 3.85 & 3.38 & 3.65 & 3.67 & 6.08 & 0.39 & 0.168 \\
\hline \multirow[t]{2}{*}{ Cai (mmol/L) } & $8 \mathrm{~h}$ & 0.70 & 0.85 & 0.69 & 0.80 & 0.72 & 1.02 & 0.65 & 21.13 & 0.33 & 0.064 \\
\hline & $14 \mathrm{~h}$ & 0.64 & 0.61 & 0.69 & 0.69 & 0.65 & 0.70 & 0.71 & 14.86 & 0.12 & 0.680 \\
\hline \multirow[t]{2}{*}{$\mathrm{EB}(\mathrm{mmol} / \mathrm{L})$} & $8 \mathrm{~h}$ & -5.37 & -6.14 & -5.93 & -6.46 & -7.08 & -5.56 & -6.40 & 21.89 & 1.90 & 0.693 \\
\hline & $14 \mathrm{~h}$ & -4.81 & -5.85 & -4.93 & -5.63 & -4.91 & -4.38 & -4.99 & 28.78 & 2.10 & 0.889 \\
\hline \multirow[t]{2}{*}{$\mathrm{HCO}_{3}(\mathrm{mmol} / \mathrm{L})$} & $8 \mathrm{~h}$ & 20.6 & 20.1 & 20.1 & 19.8 & 19.2 & 20.3 & 19.6 & 7.47 & 2.07 & 0.921 \\
\hline & $14 \mathrm{~h}$ & 21.4 & 20.4 & 21.4 & 20.8 & 21.2 & 21.3 & 21.4 & 6.57 & 1.97 & 0.952 \\
\hline \multirow[t]{2}{*}{ Osm (mOsm/kg) } & $8 \mathrm{~h}$ & 306 & 306 & 303 & 304 & 306 & 305 & 303 & 0.98 & 4.05 & 0.569 \\
\hline & $14 \mathrm{~h}$ & 305 & 310 & 306 & 303 & 306 & 305 & 304 & 0.99 & 5.43 & 0.434 \\
\hline
\end{tabular}

${ }^{1}$ Coefficient of variation ${ }^{2}$ Standard error of the mean $(n=6) .{ }^{3}$ Before animals fed. ${ }^{4} 6 \mathrm{~h}$ after after animals fed. 
urine density showed no significant differences among treatments. Urine $\mathrm{pH}$ was affected by treatments, being significantly different between control diet experimental diets, with DLM 2.56g S/kg and MHA at both doses of sulfur $(\mathrm{P}<0.001$, Table 3$)$. When the effect of sulfur source was verified, calcium sulfate showed lower efficiency in urine acidification when compared to the other sources $(\mathrm{P}<0.001)$. There were significant differences in the excretion of electrolytes. Cats fed with MHA diet $(1.28 \mathrm{~S})$ had increased renal excretion of $\mathrm{Ca}^{2+, \mathrm{Na}^{+}}, \mathrm{K}^{+}$, and $\mathrm{Cl}^{-}$when compared to the control diet. Phosphorus excretion was higher in cats fed with DLM $\operatorname{diet}(2.56 \mathrm{~S})$ and MHA. Only cats fed with MHA diet (2.56 S) showed significantly higher excretion of sulfur compared to control diet $(\mathrm{P}<0.05$; Table 3$)$.

There was no correlation between urinary $\mathrm{pH}$ and electrolyte excretion. Sulfur excretion was correlated only with $\mathrm{Mg}^{2+}$ excretion $\left(\mathrm{R}^{2=0.55, \mathrm{P}<0.001}\right)$, and this demonstrated the high correlation with $\mathrm{Na}^{+}$ $\left(\mathrm{R}^{2=0.74, \mathrm{P}<0.001}\right), \mathrm{K}^{+}\left(\mathrm{R}^{2=0.74, \mathrm{P}<0001}\right)$, phosphorus $\left(\mathrm{R}^{2=0.72 \text {, }}\right.$ $\left.{ }^{\mathrm{P}<} 0.001\right)$ and $\mathrm{Cl}^{-}$excretion $\left(\mathrm{R}^{2=0.70, \mathrm{P}<0.001)}\right.$ (Table 4).

\section{DISCUSSION}

The hypocalcemia reported in this study (reference values of Cai: 1.15 to 1.3, DIBARTOLA, 2006) may possibly be explained by the use of heparin in the syringe. Heparin tends to dilute ionized calcium, decreasing its value in the sample (SCHENCK \& CHEW, 2008) (Table 2).

The results showed that calcium sulfate showed lower efficiency in urine acidification compared to other sources $(\mathrm{P}<0.001)$. Electrolyte balance of calcium sulfate is zero because the positive divalent calcium charge counteracts the negative divalent anion sulfate $\left(\mathrm{SO}^{2-}\right)$ charge. For this reason, calcium sulfate should not influence the acid-base balance and would not change urinary $\mathrm{pH}$. The addition of calcium sulfate resulted in slight, but not significant, urinary acidification. This result may be related to the alkalizing effect of calcium, which was not strong enough to withdraw the acidifying effects of sulfur. Conversely, the BE of the diet with calcium sulfate was around $42 \mathrm{mEq} / \mathrm{kq}$, which is less than control diet $(99.93 \mathrm{mEq} / \mathrm{kq})$ and causes a decrease in urinary $\mathrm{pH}$, showing that other factors not only electrolyte balance can affect urinary $\mathrm{pH}$.

CANH et al. (1998) investigated the effects of calcium sulfate (CaSO4), calcium chloride $(\mathrm{CaCl} 2)$, calcium carbonate $(\mathrm{CaCO} 3)$ and calcium benzoate $(\mathrm{C} 14 \mathrm{H} 10 \mathrm{CaO} 4)$ in diets for finishing pigs. The authors added these sources based on the amount of calcium $(7$ and $10 \mathrm{~g} \mathrm{Ca} / \mathrm{kg}$ ) in the diet with high EB (320mEq/kg DM) and low EB (100mEq/kg DM). The authors observed that calcium sulfate at both doses acidified urine, and the highest dose led to the greatest acidification. The result was similar to urine acidification caused by the ingestion of diets containing calcium chloride. The authors explained that $\mathrm{Cl}$ - and SO42- anions have higher absorption rate in the intestine than $\mathrm{Ca} 2+$. Furthermore, $\mathrm{Ca} 2+$ is maintained in the body, especially in bones (KEMME-KROONSBERG, 1993), and has low urinary excretion and blood circulation (GUYTON \& HALL, 2011). Conversely, in the present study, the fact that calcium sulfate was the sulfur source less efficient in acidifying urine suggests that $\mathrm{Ca} 2+$ positively influenced urine $\mathrm{pH}$, because all sources initially contained the same amount of sulfur. Another fact that may have influenced this parameter may be the different digestibility of the sources used, altering the effect of these and unbalancing the equal amounts of $\mathrm{S}$ in the diets, unfortunately in this study this was not evaluated.

DLM and MHA did not result in differences in urinary $\mathrm{pH}$ each other, but they differed in the control group. The acidifying effects of DLM supplementation were also confirmed by FUNABA et al. (2000), who showed that the addition of $3 \%$ DLM acidified feline urine $\mathrm{pH}$ compared to the group without addition of DLM. When added at $1 \%$, DLM did not show efficacy. In the present study, supplementation of $1.2 \%$ DLM was not effective in reducing urinary $\mathrm{pH}$, but $2.56 \%$ was, in comparison to the control group (Table 3).

Studies about MHA as urinary acidifier have not received much attention and there are no published data regarding its effectiveness in cats. MIDDELBOS et al. (2006) evaluated the effect of DLM and MHA supplementation $(0.1 \%$ and $0.2 \%)$ on canine urinary $\mathrm{pH}$, and supplements were not effective in acidifying urine $\mathrm{pH}$, perhaps because the doses used were very low. However, in the study of MIDDELBOS et al. (2006) cats fed with a diet with $0.1 \%$ MHA had a lower concentration of postprandial urinary calcium $(\mathrm{mmol} / \mathrm{L})$ than cats fed with diets with $0.1 \%$ DLM $(\mathrm{P}<0.10)$, unlike results reported in our study, which MHA diets increased urine calcium excretion compared with calcium sulfate.

According to MARTÍN-VENEGAS et al. (2006), MHA is converted into L-Met through two pathways: alpha carbon oxidation and transamination. The authors showed that there is a conversion of MHA into L-Met in the small intestines of chickens and MHA provides higher cysteine concentrations in relation 
Table 3 - Urine characteristics and macroelements intake and excretion by urine of cats.

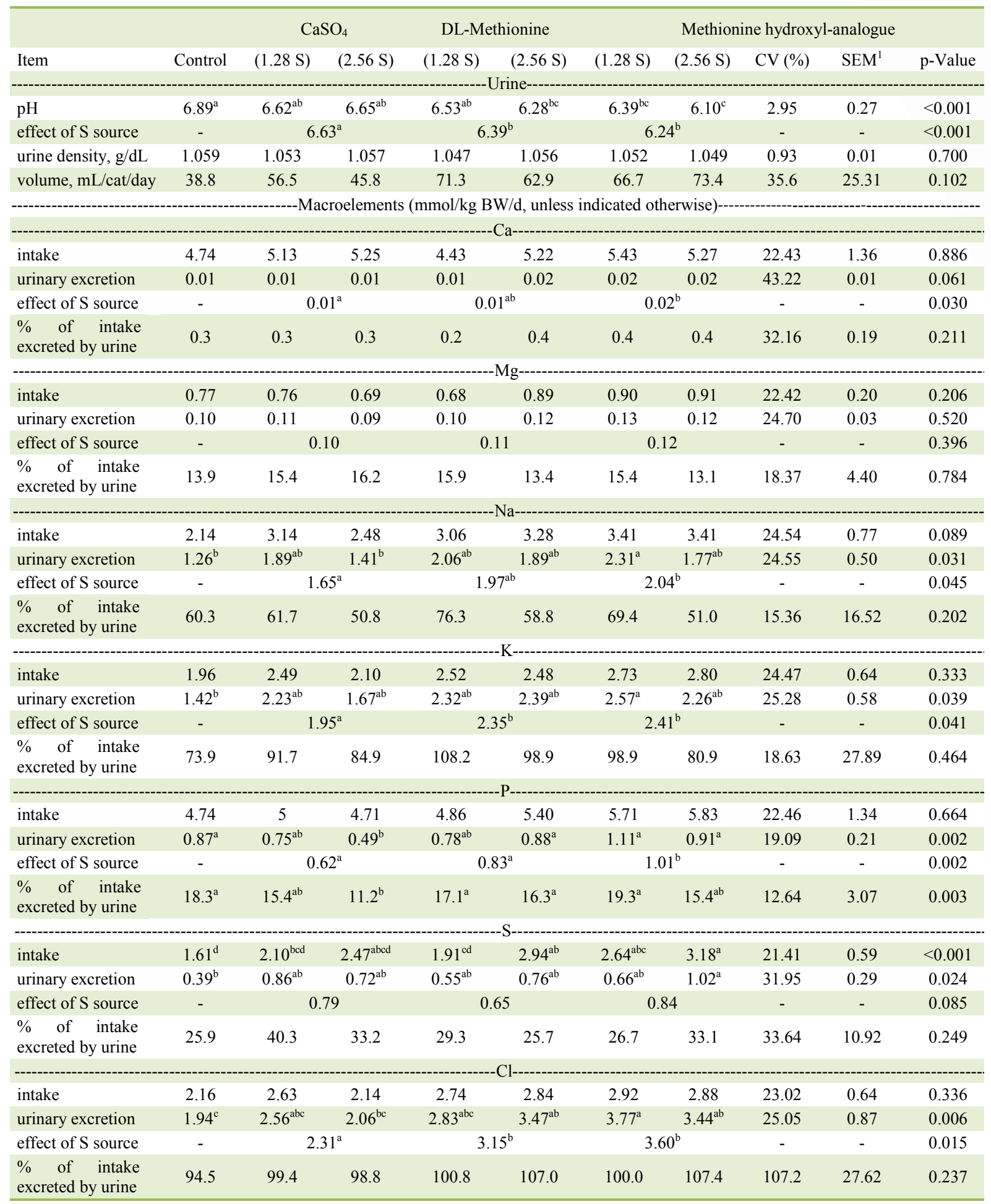

${ }^{\text {abc }}$ Means not sharing the same superscripts are significant different between feeding groups $(\mathrm{P}<0.05) .{ }^{1}$ Standard error of the mean $(\mathrm{n}=6)$. 
Table 4 - Correlation between the electrolytes excreted in the urine of cats.

\begin{tabular}{|c|c|c|c|c|c|c|c|c|}
\hline Variables & $\mathrm{pH}$ & $\mathrm{Ca}$ & $\mathrm{Mg}$ & $\mathrm{Na}$ & $\mathrm{K}$ & $\mathrm{P}$ & $\mathrm{S}$ & $\mathrm{Cl}$ \\
\hline $\mathrm{pH}$ & 1 & NS & NS & NS & NS & NS & NS & NS \\
\hline $\mathrm{Ca}$ & & 1 & NS & NS & $0.32^{\mathrm{a}}$ & $0.34^{\mathrm{a}}$ & NS & $0.35^{\mathrm{a}}$ \\
\hline $\mathrm{Mg}$ & & & 1 & $0.74^{\mathrm{b}}$ & $0.74^{\mathrm{b}}$ & $0.72^{\mathrm{b}}$ & $0.55^{\mathrm{b}}$ & $0.70^{\mathrm{b}}$ \\
\hline $\mathrm{Na}$ & & & & 1 & $0.91^{\mathrm{b}}$ & $0.80^{\mathrm{b}}$ & NS & $0.83^{b}$ \\
\hline K & & & & & 1 & $0.78^{b}$ & NS & $0.86^{\mathrm{b}}$ \\
\hline $\mathrm{P}$ & & & & & & 1 & NS & $0.77^{\mathrm{b}}$ \\
\hline S & & & & & & & 1 & NS \\
\hline $\mathrm{Cl}$ & & & & & & & & 1 \\
\hline
\end{tabular}

${ }^{\mathrm{a}} \mathrm{P}<0.05 ;{ }^{\mathrm{b}} \mathrm{P}<0.001$.

to DLM, suggesting that MHA is preferably shifted through the transsulfuration route and subsequent formation of sulfate ions. A further explanation of the acidifying effect of MHA is that MHA does not have nitrogen in its molecule, and must receive an $\mathrm{N}$ in the liver to turn into L-methionine (L-Met). The result is lower nitrogen excretion, with lower ammonia excretion and lower acid buffering in the urine.

LEMANN \& RELMAN (1959) evaluated the effects of the DLM sulfur metabolism in humans. They observed that the urine $\mathrm{pH}$ seemed to be related to the acid-base balance, but was independent of the amount of sulfate excreted. Associated with urinary acidification, the authors observed an increase in "net acid", mainly in the form of ammonium. They also observed high potassium, calcium and phosphate excretion, probably originated from titratable acids (buffers). Approximately $70 \%$ of sulfur supplied by DLM was excreted as inorganic sulfate. Reactions that lead to the formation of this compound are the sole source of endogenous acid derivatives from sulfur metabolism. The authors suggested that for each mole of oxidized sulfur, there is the production of two equivalents of hydrogen ions, being the hydrogen source part of the methionine metabolism, generated by oxidation of cysteine into cysteine sulphinic acid and deamination or transamination of cysteine sulphinate into $\beta$-sulphinyl pyruvate. The final oxidation of sulfite to sulfate does not yield additional acid.

In relation to the urinary excretion of electrolytes in cats, few studies have evaluated such information and all are different from those verified in this study. In an earlier study, PALMORE et al. (1978) evaluated the dietary effects of feline urine. More recently, WAGNER et al. (2006) verified the influence of feeding of excess bases on urine parameters in cats; and PASSLACK \& ZENTEK (2013) investigated the impact of calcium $(\mathrm{Ca})$ and phosphorus $(\mathrm{P})$ on the feline urine composition. Table 3 shows the results of the urinary excretion of electrolytesreported in this study. Calcium excretion was influenced by sulfur source. Urinary calcium excretion was quite low (less than $0.5 \%$ of calcium intake) and an increase in urinary calcium was observed in MHA treatments, even though it biological importance is possible negligible. LULICH et al. (2004) reported urinary calcium excretion of $0.018 \pm 0.015 \mathrm{mmol} / \mathrm{kg}$ of body weight (BW) per $24 \mathrm{~h}$ in cats fed with a diet containing $0.84 \%$ calcium, which is similar to values reported in this study. In relation to $\mathrm{Mg}^{2+}$, the mean value found by LULICH et al. (2004) was $0.033 \pm 0.016 \mathrm{mmol} / \mathrm{kg}$ BW per $24 \mathrm{~h}$ in cats fed with a diet containing $0.07 \%$ $\mathrm{Mg}^{2+}$, less than values reported in this study because diets contained practically twice as much; however, urinary $\mathrm{pH}$ influences the $\mathrm{Mg}$ excretion, and the diets of the studies and the sources used are different, which makes the comparison between studies difficult. They reported urinary $\mathrm{Na}^{+}$concentration of $1.149 \pm 0.524$ and $\mathrm{K}^{+}$of $1.684 \pm 0.479 \mathrm{mmol} / \mathrm{kg} \mathrm{BW}$ per $24 \mathrm{~h}$ in cats fed with diet containing $0.28 \% \mathrm{Na}^{+}$ and $0.72 \% \mathrm{~K}^{+}$, values similar to those found in this experiment. $\mathrm{K}^{+}$excretion is mostly urinary (90-95\%) and in situations of acidosis, increased extracellular potassium occurs because the high availability of $\mathrm{H}^{+}$ions decreases the activity of the $\mathrm{Na}^{+} / \mathrm{K}^{+}$pump, reducing the uptake of $\mathrm{K}^{+}$by cells, which increases the extracellular concentration and increases urinary 
excretion. Similar results regarding increased $\mathrm{K}^{+}$ excretion were found by LEMANN \& RELMAN (1959). No differences were reported in $\mathrm{Na}^{+}$excretion when assessing the relationship between sulfur metabolism and excretion of electrolytes in humans.

LULICH et al. (2004) found $0.530 \pm$ $0.271 \mathrm{mmol} / \mathrm{kg} \mathrm{BW}$ of phosphate per $24 \mathrm{~h}$ in cats fed with a diet containing $0.68 \% \mathrm{P}$. The amounts of phosphate excretion were close to those reported in this study. However, phosphate excretion was significantly lower in cats fed with a diet containing calcium sulfate $(2.56 \mathrm{~S})$ compared to a diet containing MHA (1.28 S). This may be due to the higher $\mathrm{Ca}^{2+}$ intake, which reduces the urinary excretion of phosphorus and magnesium. This can be explained by the formation of an insoluble calcium-magnesiumphosphate complex in the lumen of the intestine, which lowers the concentration of soluble phosphorus and magnesium (PASTOOR et al., 1994).

LULICH et al. (2004) found mean chloride concentration of $1.716 \pm 0.842 \mathrm{mmol} / \mathrm{kg} \mathrm{BW}$ per $24 \mathrm{~h}$ in cats fed with a diet containing $0.6 \%$ chlorine. The $\mathrm{Cl}^{- \text {values }}$ reported in this experiment were higher. One possible explanation may be acidosis due to increased concentration of $\mathrm{H}^{+}$ions, which combine with ammonia generating ammonium ion, being excreted as ammonium chloride (ALLEN \& KRUGER, 2000).

\section{CONCLUSION}

The DLM at the $2.56 \mathrm{~g} \mathrm{~S} / \mathrm{kg}$ level and the MHA at the levels, 1.28 and $2.56 \mathrm{~g} \mathrm{~S} / \mathrm{kg}$ acidified the urinary $\mathrm{pH}$. Calcium sulfate; although, not differentiated from the control diet, has been shown to alter $\mathrm{pH}$ despite its zero electrolyte balance. Apparently, the alkalizing effect of calcium was not sufficient to void sulfate acidification of the urine. Treatments showed no alteration of the acid-base balance of the animals or affect the consumption of the diets.

\section{ACKNOWLEDGEMENTS}

To Mogiana Alimentos Ltda (Guabi), for the financial, technical support. To Coordenação de Aperfeiçoamento de Pessoal de Nivel Superior (CAPES) foundation for the author supported.

\section{BIOETHICS AND BIOSSECURITY COMMITTEE APPROVAL}

All experimental procedures were approved by the Ethics Research Committee for Animal Welfare of the College of Agrarian and Veterinary Sciences, Universidade Estadual Paulista (protocol number 017648/11).

\section{AUTHORS' CONTRIBUTIONS}

All authors contributed equally for the conception and writing of the manuscript. All authors critically revised the manuscript and approved of the final version.

\section{REFERENCES}

ASSOCIATION OF AMERICAN FEED CONTROL OFFICIALS (AAFCO). Methods for substantiating nutritional adequacy of dog and cat foods. Oxford: Association of American Feed Control Officials, 2008. Available from: <http://www.aafco.org $>$. Accessed: May 20, 2017.

ALLEN, T.A., KRUGER, J.M. Small Animal Clinical Nutrition. In: Feline lower urinary tract disease. Topeka: Mark Morris Associates, 2000. p.689-723.

ASSOCIATION OF OFFICIAL ANALYTICAL CHEMISTS (AOAC). Official Methods of Analysis. Gaithersburgs: Association of Official Analytical Chemists, 2006, p. 1141.

BARTGES, J.W. Feline Calcium Oxalate Urolithiasis: Risk factors and rational treatment approaches. Journal of Feline medicine and Surgery, v.18, p.712-22, 2016. Available from: $<$ http://journals.sagepub.com/doi/abs/10.1177/1098612X1666 0442?url_ver=Z39.88-2003\&rfr_id=ori\%3Arid\%3Acrossref. org\&rfr_dat $=$ cr_pub\%3Dpubmed\& $\$$. Accessed: Jun. 02, 2017. doi: $10.1177 / 1098612$ X16660442.

BARTGES, J.W.; CALLENS, A.J. Urolithiasis. Veterinary Clinics: Small Animal Practice, v.45, p.747-768, 2015. Available from: $\quad<$ http://www.vetsmall.theclinics.com/article/S01955616(15)00046-7/fulltext>. Accessed: Jun. 07, 2017. doi: 10.1016/j.cvsm.2015.03.001.

CANH, T.T. et al. Influence of electrolyte balance and acidifying calcium salts in the diet of growing-finishing pigs on urinary $\mathrm{pH}$, slurry $\mathrm{pH}$ and ammonia volatilization from slurry. Livestock Production Science, v.56, p.1-13, 1998. Available from: <http:// www.sciencedirect.com/science/article/pii/S0301622698001481>. Accessed: Jun. 07, 2017. doi: 10.1016/S0301-6226(98)00148-1.

DIBARTOLA, S.P. Fluid therapy in small animal practice. Philadelphia: Pennsylvania, 2006. 611p.

FUNABA, M,T. et al. Effect of supplementation of dry cat food with DL-Methionine and ammonium chloride on struvite activity product and sediment in urine. Journal of Veterinary medical Science, v.36, p.337-339, 2000. Available from: <https://www. jstage.jst.go.jp/article/jvms/63/3/63_3_337/_article>. Accessed: Apr. 28, 2017. doi: 10.1292/jvms.63.337.

GRIYTH, D.P.; DUNN, D. Collection and preservation of urine for biochemical analyses. Investigative Urology, v. 15, p. 459461, 1978. Available from: <https://www.ncbi.nlm.nih.gov/ pubmed/649294>. Accessed: Apr. 27, 2017.

GUYTON, A.C.; HALL, J.E. Tratado de fisiologia médica. Rio de Janeiro: Guanabara Koogan, 2011. 1176p.

KEMME-KROONSBERG, C. Nutrition and acid-base balance of pigs, a review. Lelystad : Institute for Animal Science and Health, 1993. 69p. 
KIENZLE, E. et al. Influence of food composition on the urine $\mathrm{pH}$ in cats. Journal of Nutrition, v.121, p.87-88, 1991. Available from: <http://jn.nutrition.org/content/121/11_Suppl/S87.long $>$. Accessed: Apr. 28, 2017

LANGSTON, C. et al. Diagnosis of urolithiasis. Compendium on Continuing Education for the Practising Veterinarian, v.30, p.447-455, 2008. Available from: <https://pdfs.semanticscholar. org/7f36/7a099b84146169dacded71e669630d773753.pdf $>$. Accessed: Apr. 28, 2017.

LEMANN, J.; RELMAN, A.S. The relationship of sulphur metabolism to acid-base balance and electrolyte excretion: The effects of DL-Methionine in normal man. Journal of Clinical Investigation, v.38, p.2215-2223, 1959. Available from: $<$ https://www.ncbi.nlm.nih.gov/pmc/articles/PMC293313/>. Accessed: May 19, 2017.

LULICH, J.P. et al. Effects of diet on urine composition of cats with calcium oxalate urolithiasis. Journal of the American Animal Hospital Association, v.40, p.185-191, 2004. Available from: $\quad<$ http://jaaha.org/doi/10.5326/0400185?url ver=Z39.882003\&rfr_id=ori:rid:crossref.org\&rfr_dat $=$ cr_pub\%3dpubmed $>$. Accessed: May 09, 2017. doi: 10.5326/0400185.

LULICH, J.P. et al. ACVIM small animal consensus recommendations on the treatment and prevention of uroliths in dogs and cats. Journal of Veterinary Internal Medicine, v.30, p.1564-1574, 2016. Available from: <https://dx.doi.org/10.1111/ jvim.14559>. Accessed: May 11, 2017. doi: 10.1111/jvim.14559.

MARKWELL, P.J. et al. The effect of diet on lower urinary tract diseases in cats. The Journal of Nutrition, v.128, p. 2753 2757, 1998. Available from: <https:/www.ncbi.nlm.nih.gov/ pubmed/9868257>. Accessed: May 9, 2018

MARTÍN-VENEGAS, R. et al. Conversion of the methionine hydroxy analogue DL-2- hydroxy-(4-methylthio) butanoic acid to sulphur-containing amino acids in the chicken small intestine. Poultry Science, v.85, p.1932-1938, 2006. Available from: $<$ https://www.ncbi.nlm.nih.gov/pubmed/17032826>. Accessed: Apr. 28, 2017. doi: 10.1093/ps/85.11.1932.
MIDDELBOS, I.S. et al. Effects of dietary supplementation of DL-methionine or 2-hydroxy-4-(methylthio)-butanoic acid on food intake, nutrient digestibility, nitrogen balance, urinary and blood metabolites in healthy, growing dogs. Archives of Animal Nutrition, v.60, p.301-316, 2006. Available from: $<$ http:// www.tandfonline.com/doi/full/10.1080/17450390600785483>. Accessed: Apr. 28, 2017. doi: 10.1080/17450390600785483.

NATIONAL RESEARCH COUNCIL (NRC). Nutrient requirements of dogs and cats. Washington : The National Academies Press, 2006. 424p.

PALMORE, W.P. et al. Effects of diet on feline urine. Laboratory Animal Science, v.28, p.551-555, 1978. Available from: <https:// www.ncbi.nlm.nih.gov/pubmed/723217>. Accessed: May 09, 2018.

PASSLACK, N.; ZENTEK, J. Urinary calcium and oxalate excretion in healthy adult cats are not affected by increasing dietary levels of bone meal in a canned diet. PLoS One, v.5, p.e70530, 2013. Available from: <http://journals.plos.org/plosone/ article? $\mathrm{id}=10.1371 /$ journal.pone.0070530>. Accessed: May 09, 2018. doi: 10.1371/journal.pone.0070530.

PASTOOR, F.J. et al. Increasing calcium intakes lower urinary concentration of phosphorus and magnesium in adult ovariectomized cats. Journal of Nutrition, v.124, p.299-304, 1994. Available from: <http://jn.nutrition.org/content/124/2/299. long $>$. Accessed: Apr. 28, 2017

SCHENCK, P.A.; CHEW, D.J. Hypercalcemia: A quick reference. Veterinary Clinics of North America: Small Animal Practice, v.38, p.449-455, 2008. Available from: <http://www.sciencedirect. com/science/article/pii/S0195561608000338?via\%3Dihub $>$. Accessed: Apr. 28, 2017. doi: 10.1016/j.cvsm.2008.01.020.

WAGNER, E. et al. Influence of the feed base excess on urine parameters in cats. Journal of Animal Physiology and Animal Nutrition, v.90, p.19-24, 2006. Available from: <http:// onlinelibrary.wiley.com/doi/10.1111/j.1439-0396.2005.00613.x/ abstract; jsessionid $=0538070126 \mathrm{D} 31 \mathrm{BEB} 32 \mathrm{E} 2 \mathrm{~A} 37 \mathrm{D} 8 \mathrm{AEC}$ ED93.f03t02>. Accessed: May 28, 2017. doi: 10.1111/j.14390396.2005 .00613 . 